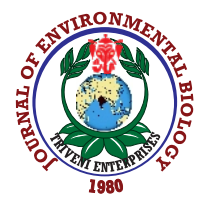

\title{
Influence of Ascophyllum nodosum extract, homobrassinolide and triacontanol on fruit retention, yield and quality of mango
}

\author{
A. Dash', D. Samant ${ }^{2 *}$, D.K. Dash', S.N. Dash ${ }^{1}$ and K.N. Mishra ${ }^{3}$ \\ 'Department of Fruit Science and Horticulture Technology, Odisha University of Agriculture and Technology, Bhubaneswar-751 003, India \\ ${ }^{2}$ ICAR-IIHR-Central Horticultural Experiment Station, Bhubaneswar-751 019, India \\ ${ }^{3}$ Department of Soil Science and Agricultural Chemistry, Odisha University of Agriculture and Technology, Bhubaneswar-751 003, India \\ *Corresponding Author Email : horti.deepa@gmail.com
}

\begin{tabular}{lll}
\hline Received: 04.06 .2020 & Revised: 23.10 .2020 & Accepted: 09.12 .2020 \\
\hline
\end{tabular}

\section{Abstract}

Aim: To evaluate the efficacy of foliar application of Ascophyllum nodosum extract, homobrassinolide, and triacontanol for improving fruit retention, yield, and quality in mango.

Methodology: The experiment was laid out in a randomized block design with 10 treatments, comprising Ascophyllum nodosum extract (1000, 3000, and 5000 $\mathrm{ppm})$, homobrassinolide $(0.1,0.3$, and $0.5 \mathrm{ppm})$, triacontanol $(1,3$, and $5 \mathrm{ppm})$, and water as control. Treatments were foliar sprayed at panicle initiation, pea, and marble stages of fruit growth. Observations were recorded on flowering, fruiting, yield, and fruit quality parameters.

Results: All the treatments of Ascophyllum nodosum extract and triacontanol exhibited significant improvement in fruit retention, fruit weight, yield, and fruit quality parameters over control. However, 3000 and 5000 ppm Ascophyllum nodosum extract treatments outperformed all the treatments of triacontanol. Plants sprayed with $5000 \mathrm{ppm}$ Ascophyllum nodosum extract recorded the maximum value for fruit retention $(48.15,36.74,29.48$, and $25.76 \%$ at $3,6,9$, and 12 weeks after pea stage, respectively), number of fruits ( 133.25 per tree), fruit weight (188.84 g per fruit), and yield (25.16 kg per tree), whereas the lowest values were recorded under control. With respect to fruit quality, $3000 \mathrm{ppm}$ ANE produced the fruits with the highest TSS $\left(19.62^{\circ} \mathrm{B}\right)$, whereas the highest TSS/acid ratio was recorded with 5000 ppmANE (62.29) treatment.

Interpretation: In mango, foliar application of Ascophyllum nodosum extract (3000-5000 ppm) thrice at panicle initiation, pea, and marble stages of fruit growth

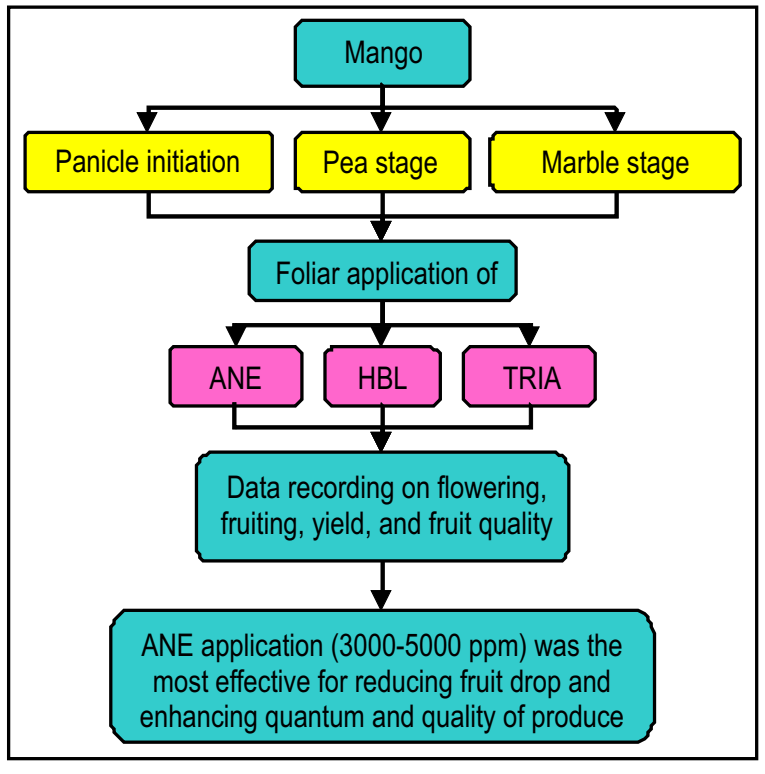
is effective for reducing fruit drop and enhancing quantum and quality of produce.

Key words: Ascophyllum nodosum, Biostimulant, Fruit retention, Mango yield, Triacontanol

How to cite : Dash, A., D. Samant, D.K. Dash, S.N. Dash and K.N. Mishra: Influenece of Ascophyllum nodosum extract, homobrassinolide and triacontanol on fruit retention, yield and quality of mango. J. Environ. Biol., 42, 1085-1091 (2021). 


\section{Introduction}

Mango (Mangifera indica L.), belonging to the family Anacardiaceae is one of the choicest tropical fruits. It is often referred to as 'King of fruits' in the tropical world by virtue of its wide range of edapho-climatic adaptability, varietal diversity, scale of production, multifarious uses, and exceptional nutritional and organoleptic properties. It enjoys mass popularity in the Orient, particularly in India, where, it holds a great cultural, socioeconomic, and religious significance with a long history of cultivation. Its popularity and importance in Indian horticulture can be easily adjudged by the extent of area under this crop. It covers approximately $35 \%$ of the country's area under fruit crops. Over the last 27 years (1991-2017), mango has recorded a 2.1-fold increase in area from 1.08 million ha to 2.26 million ha, whereas, a 2.5 -fold increase in production from 8.72 million tonnes to 21.82 million tonnes. On the productivity front, the country has not shown significant progress and is yet to meet the expectation of domestic demand as well as export requirement. Heavy fruit drop is one of the major constraints to realise high yield potential of mango, despite profuse flowering (Ghosh, 2016; Momin et al., 2016). Fruit abscission, occurring at all stages of fruit growth and development is a complex physiological process that initiates in response to several biotic and abiotic factors (Banyal and Sharma, 2015; Singh et al., 2005). Among several causes, hormonal imbalance and competition among developing fruits for photo-assimilates are the major factors (Ram, 1992; Bhamare et al., 2014).

Mango experiences a long period of stress during flowering and fruiting on account of prevailing high soil and atmospheric temperature, low atmospheric humidity, and reduced soil-moisture regime. In an adaptive response to abiotic stress, plant up-regulates biosynthesis of abscission promoters, viz., abscisic acid and ethylene, whereas, down-regulates production of abscission inhibitors, viz., auxin, cytokinin, and gibberellin (Sawicki et al., 2015; Dodd, 2005). Stress-induced hormonal imbalance in plants further reduces its photosynthetic efficiency and carbohydrate influx to developing fruit (Estornell et al., 2013). All these events of hormonal signaling culminate into fruit drop via activation of abscission zone. Therefore, the problem of heavy fruit drop in mango can be minimized by foliar application of anti-stress plant growth regulators, viz., homobrassinolide (HBL), seaweed-based biostimulant, viz., Ascophyllum nodosum extract (ANE), and photosynthesis enhancer, viz., triacontanol (TRIA) during flowering and fruit development.

Homobrassinolide is one of the 70 analogues identified under the novel class of steroidal phytohormones called brassinosteroids (Bajguj and Tretyn, 2003). Brassinosteroids (BRs) are omnipresent in the plant kingdom and acknowledged as sixth class of phytohormone. BRs regulate a wide range of growth, developmental, and physiological processes in the plants, viz., cell elongation, germination, root growth, vascular differentiation, flowering, fertility, senescence, abscission, source-sink relationship, and photosynthesis (Deng et al., 2007). Besides, BRs are suggested to have a role in the production of growth-promoting plant hormones, viz., auxin and cytokinin, and impart stress-protective properties in plants against several abiotic stresses, viz., extremes of temperature, water stress (Ahmad et al., 2020; Bajguj and Hayat, 2009). Ascophyllum nodosum is an intertidal species of brown algae growing exclusively in the cold and clean water of the North Atlantic. Extract of this seaweed contains essential nutrients, enzymes, vitamins, growth regulators, phytohormone signalling/elicitor molecules, betain, alginic acid, mannitol, and amino acids. Application of ANE on plants enhances their stress tolerance ability by modulating the expression of genes involved in the biosynthesis of stress mitigating compounds, viz., antioxidants, mannitol, proline, and alginic acid (Shukla et al., 2019; Norrie, 2016; Battacharyya et al., 2015; Wally et al., 2013). Triacontanol is a long-chain primary alcohol composed of 30 carbon atoms. It is ubiquitously found in nature as a constituent of bee and plant waxes. It is a broad-spectrum plant growth regulator influencing a wide range of physiological activities of plants. TRIA is suggested to have a role in the up-regulation of genes involved in photosynthesis, translocation, and accumulation of photosynthates. It also reduces transpiration and respiration losses and enhances uptake of nutrients (Naeem et al., 2012; Chen et al., 2002).

In mango, the role of exogenous application of plant growth regulators, particularly, auxins (NAA and 2,4-D) and gibberellins $\left(\mathrm{GA}_{3}\right)$ during flowering and various stages of fruit development, viz., pea and marble has been studied extensively for enhancing fruit retention, yield, and quality of produce (Ghosh, 2016; Prakash and Ram, 1986; Singh and Ram, 1983). However, anti-stress plant growth regulators and photosynthesis enhancer have not been studied adequately for the purpose despite their potential as observed by Mostafa and Kotb (2018), Mohamed and El-Sehrawy (2013), Abubakar et al. (2012), and Das et al. (2011). Therefore, keeping all these points into consideration a study was carried out to assess the effects of Ascophyllum nodosum extract, homobrassinolide, and triacontanol on fruit retention, yield, and quality in mango under hot and humid climate of Odisha, India.

\section{Materials and Methods}

The present investigation was carried out in the coastal region of India at the research farm of ICAR-IIHR-Central Horticultural Experiment Station, Bhubaneswar, Odisha during 2017-18. The climate of experimental farm is hot and humid, tropical which receives on an average $1400 \mathrm{~mm}$ annual rainfall between June to September. The climate between October to June remains dry. The soil of the experimental orchard was sandy loam $(73.40 \%$ sand, $17.25 \%$ silt, and $9.35 \%$ clay), highly acidic (pH 4.49), low in organic carbon (0.24\%), available nitrogen (186.74 kg ha ${ }^{-1}$ ) and phosphorus (12.15 kg ha $\left.{ }^{-1}\right)$, and medium in potassium (181.51 $\left.\mathrm{kg} \mathrm{ha}^{-1}\right)$. Ten-year-old mango plants variety Arka Neelachal Kesri of uniform vigour and size, planted at $4 \mathrm{~m} \times 3$ $m$ spacing, and maintained under uniform cultural practices were 
selected for the study. The experiment was laid out in a randomized block design with 10 treatments comprising $\mathrm{ANE}(\mathrm{T} 1$ : 1000, T2: 3000 , and T3: 5000 ppm), HBL (T4: 0.1, T5: 0.3, and T6: $0.5 \mathrm{ppm}), \operatorname{TRIA}(\mathrm{T} 7: 1, \mathrm{~T} 8: 3$, and T9: $5 \mathrm{ppm})$, and water as control (T10). Each treatment was replicated thrice and each replication unit had four plants. Treatments were foliar sprayed thrice at panicle initiation, pea, and marble stages of fruit growth. Three commercial products named Toggle, Double, and Vipul were used as a source of Ascophyllum nodosum extract, homobrassinolide, and triacontanol, respectively. Toggle is manufactured by Acadian Seaplants Ltd., Nova Scotia, Canada. It contains organic matter (4-5\%), $\mathrm{N}(0.1-0.3 \%), \mathrm{P}_{2} \mathrm{O}_{5}(0.4-1.2 \%)$, $\mathrm{K}_{2} \mathrm{O}(1.0-2.5 \%)$, Ca $(0.01-0.05 \%), \mathrm{Mg}(0.01-0.05 \%)$, S $(0.09-$ $0.18 \%), \mathrm{B}(5-20 \mathrm{ppm}), \mathrm{Cu}(<5 \mathrm{ppm}), \mathrm{Fe}(10-30 \mathrm{ppm}), \mathrm{Mn}(<4$ ppm), and Zn (1-10 ppm). Commercial formulations Double and Vipul are manufactured by Godrej Agrovet Ltd., Mumbai, India. The former product contains $0.04 \%$ homobrassinolide, whereas, the latter formulation has $0.1 \%$ triacontanol as an active ingredient.

Observations were recorded on leaf chlorophyll content; characteristics of flowering and fruiting, viz., flowering intensity (\%), panicle length and width $(\mathrm{cm})$, hermaphrodite flower $(\%)$, and fruit retention (\%); yield ( $\mathrm{kg}$ per tree) and yield contributing parameters, viz., fruit weight (g per fruit) and no. of fruits per plant; and on fruit quality parameters, viz., pulp content (\%), dry matter content (\%), TSS ( $\left.{ }^{\circ} \mathrm{B}\right)$, acidity ( $\%$ equivalent of citric acid), TSS/acid ratio, sugar content (\%) and vitamin C (mg $100 \mathrm{~g}^{-1}$ of pulp). For estimation of chlorophyll content, 20 newly emerged shoots (five in each direction of the plant canopy, i.e., east, west, north, and south) were tagged in each tree after first foliar application of treatments. Thereafter, two mature leaves (four months old) were selected from the middle portion of each tagged shoot. Chlorophyll content was estimated by placing the SPAD chlorophyll meter on 5 points avoiding midrib and expressed in SPAD unit. Direct sunlight was avoided while taking the observations.

In order to estimate flowering intensity, panicle bearing shoots were counted in four directions of the plant canopy using 1 $\mathrm{m}^{2}$ quadrate and expressed in percentage. To record various characteristics of flowering and fruiting, 20 panicles (five in each direction of the plant canopy) were randomly selected and tagged on each tree at full bloom stage. Panicle length was measured from its point of origin to tip using a measuring tape, whereas, the width was recorded at the widest point. At full bloom hermaphrodite flowers per panicle were counted and expressed in percentage. Fruit retention was computed by counting the number of fruits on tagged panicles at pea stage, thereafter, at an interval of three-week till fruit harvesting, i.e., at 3, 6, 9, and 12 weeks after pea stage (WAPS) and expressed in percentage.

Fruits were harvested at full maturity, weighed with physical balance and yield was expressed in kg per tree. The average fruit weight was computed by dividing the fruit yield by the number of fruits per tree. For recording observations on fruit quality attributes, 10 fruits of uniform maturity were sampled randomly from each tree. Fruits were ripened off of the tree by wrapping them in newspaper individually and storing such fruits in corrugated fibreboard boxes. Pulp content was worked out by subtracting peel and stone from fruit weight and expressed in percentage. Dry matter content was determined by the gravimetric method, wherein $2 \mathrm{~cm}$ wide longitudinal slice of mango was convective air-dried at $135^{\circ} \mathrm{C}$ for $2 \mathrm{hrs}$. Total soluble solid content (TSS) was determined using a hand-held digital refractometer (Hanna make), whereas, other chemical attributes of fruit quality, viz., acidity, sugar (reducing, nonreducing, and total sugar), and ascorbic acid content were estimated following the standard analytical methods of AOAC (2000). The data generated on various parameters were tabulated and statistically analyzed using OPSTAT package (Sheoran, 1998) for interpreting results and drawing conclusions.

\section{Results and Discussion}

The perusal of data on various parameters of flowering (Table 1) revealed significant improvement in flowering intensity under all the treatments of homobrassinolide and Ascophyllum nodosum extract over control. The flowering intensity in homobrassinolide treatments ranged from 67.64 to $70.37 \%$, whereas, $64.50-66.17 \%$ in Ascophyllum nodosum extract treatments. The treatment $0.5 \mathrm{ppm}$ homobrassinolide (T6) recorded maximum flowering, followed by $0.3 \mathrm{ppm}$ homobrassinolide (T5). The positive influence of $\mathrm{HBL}$ and $\mathrm{ANE}$ on flowering has also been reported by Ramani et al. (2016), Basak (2008) and Pipattanawong et al. (1996). Improvement in flowering due to HBL and ANE could be attributed to the additive and synergistic effect of HBL on flowering related hormones (Halliday, 2004) and the presence of high cytokinin and its signalling molecule in ANE (Wally et al., 2013; Brain et al., 1973). No significant variation was recorded for hermaphrodite flower percent. Triacontanol and seaweed-based biostimulant had a significant influence on panicle length and width. Both the parameters of panicle growth increased with increase in the concentration of TRIA and ANE, though the differences were found to be non-significant. Plants sprayed with 5 ppm TRIA (T9) produced the longest and widest panicles $(26.45$ and $17.13 \mathrm{~cm})$. Growth promoting effects of HBL and ANE treatments could be due to enhanced leaf chlorophyll in these treatments (Fig. 1). Similar effects of $\mathrm{HBL}$ and ANE on growth and leaf chlorophyll content were also observed by Ali et al. (2016), Manna et al. (2012) and Kumaravelu et al. (2000).

In general, fruit retention followed a decreasing trend with the advancement of fruit maturity, irrespective of treatments (Table 2). Fruit retention at three weeks after pea stage (WAPS) varied from 37.23 to $48.15 \%$, whereas, at the time of fruit maturity (12 WAPS) it ranged from 19.08 to $25.76 \%$. It is evident from the perusal of data, that foliar application of ANE (1000-5000 ppm) and TRIA (1-3 ppm) significantly improved the fruit retention in mango, whereas, $\mathrm{HBL}$ treatments failed to do so and remained at par with the control. Among various treatments of ANE (T1, T2, 
Table 1: Effect of foliar application of Ascophyllum nodosum extract (ANE), homobrassinolide (HBL), and triacontanol (TRIA) on flowering in mango

\begin{tabular}{lllll}
\hline Treatments & $\begin{array}{l}\text { Flowering } \\
\text { intensity }(\%)\end{array}$ & $\begin{array}{l}\text { Hermaphrodite } \\
\text { flowers }(\%)\end{array}$ & \multicolumn{2}{c}{ Panicle dimension (cm) } \\
\cline { 4 - 5 } & & & Length & Width \\
\hline T1 & 64.50 & 12.72 & 24.94 & 15.04 \\
T2 & 66.17 & 13.13 & 25.16 & 15.98 \\
T3 & 65.18 & 13.73 & 25.74 & 16.42 \\
T4 & 67.64 & 12.68 & 22.28 & 13.39 \\
T5 & 69.59 & 12.93 & 21.46 & 14.49 \\
T6 & 70.37 & 13.31 & 21.93 & 14.44 \\
T7 & 53.02 & 9.19 & 24.79 & 14.87 \\
T8 & 53.11 & 9.35 & 25.55 & 16.30 \\
T9 & 54.27 & 9.46 & 26.45 & 17.13 \\
T10 & 50.92 & 1.33 & 20.56 & 12.07 \\
SE $(m) \pm$ & 2.40 & NS & 1.18 & 0.84 \\
CD $(P=0.05)$ & 7.20 & 3.52 & 2.52 \\
\hline
\end{tabular}

T1= 1000 ppm ANE; T2=3000 ppm ANE; T3=5000 ppm ANE; T4=0.1 ppm HBL; T5=0.3 ppm HBL; T6=0.5 ppm HBL; T7=1 ppm TRIA; T8: 3 ppm TRIA; T9=5 ppm TRIA; T10 $=$ Control

Table 2: Effect of foliar application of Ascophyllum nodosum extract (ANE), homobrassinolide (HBL), and triacontanol (TRIA) on fruit retention and yield in mango

\begin{tabular}{|c|c|c|c|c|c|c|c|}
\hline \multirow[t]{2}{*}{ Treatments } & \multicolumn{4}{|c|}{ Fruit retention (\%) } & \multicolumn{3}{|c|}{ Fruit yield } \\
\hline & 3 WAPS & 6 WAPS & 9 WAPS & 12 WAPS & $\begin{array}{l}\text { No. of fruits } \\
\text { per tree }\end{array}$ & $\begin{array}{l}\text { Fruit weight } \\
\text { (g per fruit) }\end{array}$ & $\begin{array}{l}\text { Yield } \\
\text { (kg per tree) }\end{array}$ \\
\hline T1 & 44.73 & 33.38 & 27.06 & 23.10 & 118.86 & 182.83 & 21.72 \\
\hline T2 & 47.81 & 36.15 & 29.14 & 25.12 & 132.18 & 187.20 & 24.70 \\
\hline T3 & 48.15 & 36.74 & 29.48 & 25.76 & 133.25 & 188.84 & 25.16 \\
\hline T4 & 37.78 & 27.61 & 22.63 & 19.14 & 101.47 & 168.77 & 17.14 \\
\hline T5 & 37.94 & 27.84 & 23.12 & 19.10 & 102.69 & 170.40 & 17.43 \\
\hline T6 & 38.12 & 27.76 & 22.74 & 19.21 & 103.54 & 170.12 & 17.62 \\
\hline $\mathrm{T} 7$ & 41.32 & 30.53 & 24.75 & 21.10 & 106.86 & 181.26 & 19.32 \\
\hline T8 & 42.09 & 30.75 & 25.13 & 21.18 & 110.48 & 182.22 & 20.17 \\
\hline T9 & 44.86 & 33.47 & 27.12 & 23.27 & 121.94 & 183.50 & 22.38 \\
\hline T10 & 37.23 & 27.43 & 22.57 & 19.08 & 93.84 & 169.28 & 15.86 \\
\hline $\operatorname{SE}(\mathrm{m}) \pm$ & 0.78 & 0.83 & 0.62 & 0.54 & 3.36 & 3.67 & 0.70 \\
\hline$C D(P=0.05)$ & 2.37 & 2.51 & 1.84 & 1.63 & 10.05 & 11.16 & 2.09 \\
\hline
\end{tabular}

WAPS: Weeks after pea stage; T1=1000 ppm ANE; T2=3000 ppm ANE; T3=5000 ppm ANE; T4=0.1 ppm HBL; T5=0.3 ppm HBL; T6=0.5 ppm HBL; T7=1 ppm TRIA; T8=3 ppm TRIA; T9=5 ppm TRIA; T10= Control

and T3) and TRIA (T7, T8, and T9), the ANE treatments T2 (3000 $\mathrm{ppm})$ and $\mathrm{T} 3(5000 \mathrm{ppm})$ were found to be significantly superior over the remaining treatments. The treatment $\mathrm{T} 3$ recorded the maximum fruit retention $(48.15 \%)$ at 3 WAPS, followed by T2 $(47.81 \%)$ and both the treatments were statistically at par. The results were same for the remaining recording period $(6,9$, and 12 WAPS).

Improvement in fruit retention on applying ANE and TRIA has also been reported earlier by Momin et al. (2016), Abubakar et al. (2012) and Patil et al. (2005). The positive influence of seaweed-based biostimulant on fruit retention could be due to cytokinin-like activity. Ascophyllum nodosum extract contains cytokinin and elicitor molecules involved in the up regulation of biosynthetic pathway of cytokinin in plants (Wally et al., 2013). Elevated levels of cytokinin in ANE-treated plants can enhance the sink strength and source capacity resulting in the reduction in fruit abscission. Improvement in fruit retention by triacontanol could be attributed to its role in enhancing nutrient uptake, photosynthetic efficiency, and source-sink relationship, and to its antagonistic effect on transpiration and respiration (Naeem et al., 2012; Chen et al., 2002). In the present study, higher 
Table 3: Effect of foliar application of Ascophyllum nodosum extract (ANE), homobrassinolide (HBL), and triacontanol (TRIA) on fruit quality in mango

\begin{tabular}{|c|c|c|c|c|c|c|c|c|c|}
\hline \multirow[t]{2}{*}{ Treatments } & \multirow{2}{*}{$\begin{array}{l}\text { Pulp content } \\
(\%)\end{array}$} & \multirow{2}{*}{$\begin{array}{l}\text { Dry matter } \\
(\%)\end{array}$} & \multirow{2}{*}{$\begin{array}{l}\text { TSS } \\
\left({ }^{\circ} \mathrm{B}\right)\end{array}$} & \multirow{2}{*}{$\begin{array}{l}\text { Acidity } \\
(\%)\end{array}$} & \multirow{2}{*}{$\begin{array}{l}\text { TSS/acid } \\
\text { ratio }\end{array}$} & \multicolumn{3}{|c|}{ Sugar content (\%) } & \multirow{2}{*}{$\begin{array}{l}\text { Vitamin C (mg } \\
100 g^{-1} \text { pulp) }\end{array}$} \\
\hline & & & & & & Reducing & Non-reducing & Total & \\
\hline T1 & 68.68 & 20.25 & 19.18 & 0.35 & 55.94 & 5.43 & 9.90 & 15.33 & 32.15 \\
\hline T2 & 69.21 & 20.77 & 19.62 & 0.35 & 57.09 & 5.58 & 9.73 & 15.31 & 30.61 \\
\hline T3 & 69.43 & 20.90 & 19.29 & 0.32 & 62.29 & 5.74 & 9.66 & 15.39 & 30.81 \\
\hline T4 & 65.34 & 17.18 & 17.78 & 0.43 & 41.88 & 4.10 & 8.65 & 12.75 & 31.20 \\
\hline T5 & 65.17 & 17.51 & 17.69 & 0.40 & 44.23 & 4.23 & 8.96 & 13.18 & 34.57 \\
\hline T6 & 65.22 & 17.70 & 18.30 & 0.43 & 43.36 & 4.44 & 9.01 & 13.44 & 32.34 \\
\hline $\mathrm{T} 7$ & 68.43 & 20.52 & 18.90 & 0.35 & 55.09 & 4.92 & 9.68 & 14.60 & 35.49 \\
\hline T8 & 68.24 & 20.71 & 18.80 & 0.37 & 50.84 & 5.25 & 9.43 & 14.68 & 30.04 \\
\hline T9 & 68.63 & 21.59 & 18.92 & 0.37 & 51.02 & 5.34 & 9.49 & 14.83 & 33.16 \\
\hline T10 & 64.73 & 16.44 & 17.55 & 0.45 & 38.96 & 4.47 & 8.85 & 13.32 & 30.75 \\
\hline $\mathrm{SE}(\mathrm{m}) \pm$ & 2.41 & 0.80 & 0.41 & 0.03 & 3.79 & 0.21 & 0.36 & 0.34 & 2.87 \\
\hline $\mathrm{CD}(\mathrm{P}=0.05)$ & NS & 2.38 & 1.23 & NS & 11.33 & 0.61 & NS & 1.00 & NS \\
\hline
\end{tabular}

T1=1000 ppm ANE; T2=3000 ppm ANE; T3=5000 ppm ANE; T4=0.1 ppm HBL; T5=0.3 ppm HBL; T6=0.5 ppm HBL; T7=1 ppm TRIA; T8=3 ppm TRIA; T9=5 ppm TRIA; T10=Control

levels of leaf chlorophyll in TRIA and ANE treated plants support their role in enhancing source capacity (Fig. 1). All the treatments of Ascophyllum nodosum extract and triacontanol significantly enhanced the mango produce in terms of fruit number and yield over the control (Table 2). However, the effect of 3000 and 5000 ppm Ascophyllum nodosum extract was found to be more pronounced. Fruit number and yield followed an increasing trend with the increase in the concentration of Ascophyllum nodosum extract and triacontanol. Plants sprayed with 5000 ppm Ascophyllum nodosum extract recorded the highest fruit yield
(25.16 kg per tree) with maximum number of fruits (133.25 per tree), which was statistically at par with the yield obtained under T2 treatment (3000 ppm Ascophyllum nodosum extract). Control plants (sprayed with water) recorded the lowest value for fruit number and yield (93.84 fruits per tree and $15.86 \mathrm{~kg}$ per tree, respectively). Fruit weight also enhanced significantly by Ascophyllum nodosum extract and triacontanol treatments in a dose dependent manner. However, variation in fruit weight remained non-significant among various treatments of Ascophyllum nodosum extract and triacontanol. The maximum

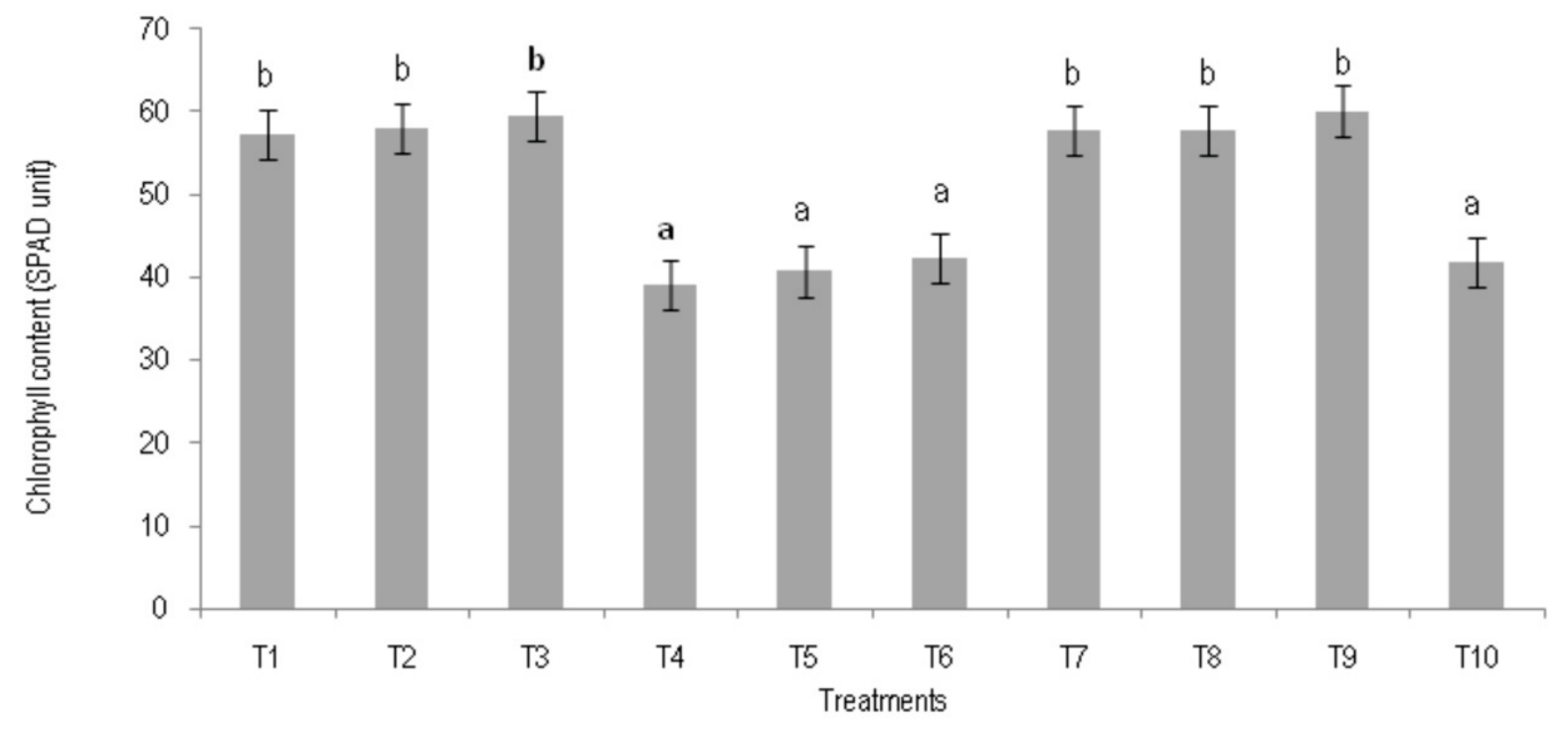

Fig. 1: Effect of Ascophyllum nodosum extract (ANE), homobrassinolide (HBL), and tiacontanol (TRIA) on leaf chlorophyll content. T1=1000 ppm ANE; T2=3000 ppm ANE; T3=5000 ppm ANE; T4= 0.1 ppm HBL; T5=0.3 ppm HBL; T6=0.5 ppm HBL; T7= 1 ppm TRIA; T8=3 ppm TRIA; T9=5 ppm TRIA; $\mathrm{T} 10=$ Control. Values are the mean of three replicates and bars represent standard error of means. Different letters represent significant difference between the treatments $(P=0.05)$. 
fruit weight (188.84 g per fruit) was recorded with T3 treatment (5000 ppmANE), whereas, the lowest ( $168.77 \mathrm{~g}$ per fruit) was with T4 treatment $(0.1 \mathrm{ppm} \mathrm{HBL})$. Our results are in line with the findings of Baba et al. (2017) and Morales-Payan and Candelas (2014). The pronounced influence of Ascophyllum nodosum extract on fruit yield observed in the present study could be attributed to improvement in flowering, fruit retention, and fruit weight (Table 1,2).

It is evident from the fruit quality data presented in Table 3 that foliar application of Ascophyllum nodosum extract and triacontanol in mango can significantly improve the fruit quality in terms of dry matter, TSS, TSS/acid ratio, reducing sugar and total sugar. Fruit quality observed under Ascophyllum nodosum extract and triacontanol treatments were found to be statistically on par. Fruits with the highest dry matter content $(21.59 \%)$ were harvested from T9-treated plants, whereas, the lowest dry matter $(16.44 \%)$ was recorded with control plants, which was on par with the values obtained under all the treatments of HBL. The ANE treatment T2 (3000 ppm) recorded the highest TSS $\left(19.62^{\circ} \mathrm{B}\right)$, followed by T3 (5000 ppm). Mango produce, harvested under T3 treatment (5000 ppm ANE) recorded the highest value for TSS/acid ratio (62.29), reducing sugar (5.74\%), and total sugar (15.39\%).

The fruit quality data further revealed insignificant improvement by treatments over the control with respect to pulp content, acidity, non-reducing sugar, and vitamin C content. Improvement in fruit quality by Ascophyllum nodosum extract could be attributed to actions and effects of nutrients, vitamins, enzymes, phytohormones, elicitor molecules present in it, viz., enhanced nutrient uptake, upregulated sugar synthesis, efficient photosynthesis, and better translocation and accumulation of carbohydrates. (Frioni et al., 2018; Mohamed and El-Sehrawy, 2013) and Khan et al., 2012). Thus, from the present investigation, it can be concluded that in mango, foliar application of Ascophyllum nodosum extract @ 3000-5000 ppm thrice at panicle initiation, pea, and marble stages of fruit growth is effective for reducing fruit drop and enhancing quantum and quality of produce.

\section{Acknowledgments}

Authors are thankful to the Director, ICAR-IIHR, Bengaluru, India and the Head, ICAR-IIHR-CHES, Bhubaneswar, India for providing facilities during the study period.

\section{Add-on Information}

Authors' contribution: A. Dash: Investigation, Lab analysis, Formal analysis; D. Samant: Writing- original draft, writing- review and editing, Methodology, Visualization, Formal analysis; Technical guidance; D.K. Dash: Methodology, Technical guidance; S.N. Dash: Methodology, Technical guidance; K.N. Mishra: Methodology, Technical guidance.

Research content: The research content of manuscript is original and has not been published elsewhere.

Ethical approval: Not applicable
Conflict of interest: The authors declare that there is no conflict of interest.

\section{Data from other sources: Not applicable}

Consent to publish: All authors agree to publish the paper in Journal of Environmental Biology.

\section{References}

Abubakar, A.R., N. Ashraf and M. Ashraf: Effect of plant biostimulants on flowering, fruit drop, yield and return bloom of Pomegranate cV. Kandhari Kabuli. Asian J. Hort., 7, 473-477 (2012).

Ahmad, H., S. Hayat, M. Ali, H. Liu, X. Chen, J. Li and Z. Cheng: The protective role of 28-Homobrassinolide and Glomus versiforme in cucumber to withstand saline stress. Plants, 9, 42 (2020).

Ali, N., A. Farrell, A. Ramsubhag and J. Jayaraman: The effect of Ascophyllum nodosum extract on the growth, yield and fruit quality of tomato grown under tropical conditions. J. Appl. Phycol., 28, 1353-1362 (2016).

AOAC: Official Methods of Analysis. $17^{\text {th }}$ Edn., Association of Official Analytical Chemist, Washington DC, USA (2000).

Baba, T.R., A. Ali, A. Kumar and M. Hussain: Effect of exogenous application of salicylic acid and triacontanol on growth characters and yield of strawberry. Pharma Innov., 6, 274-279 (2017).

Bajguz, A. and A. Tretyn: The chemical characteristic and distribution of brassinosteroids in plants. Phytochemistry, 62, 1027-1046 (2003).

Bajguz, A. and S. Hayat: Effects of brassinosteroids on the plant responses to environmental stresses. Plant Physiol. Biochem., 47, 1-8 (2009).

Banyal, S.K. and D. Sharma: Effect of hormonal treatment and mulching on fruit drop and quality in mango. J. Hortl. Sci., 10, 102-106 (2015).

Basak A.: Effect of preharvest treatment with seaweed products, Kelpak® and Goemar BM $86 \circledast$, on fruit quality in apple. Int. J. Fruit Sci., 8, 1-14 (2008).

Battacharyya, D., M.Z. Babgohari, P. Rathor and B. Prithiviraj: Seaweed extracts as biostimulants in horticulture. Sci. Hortic., 196, 39-48 (2015).

Bhamare, S.P., H.C. Patel and B. Singh: Effect of PGRs on reduction of fruit drop in mango cv. Mallika. Asian J. Hort., 9, 510-511 (2014).

Brain, K.R., M.C. Chalopin, T.D. Turner, G. Blunden and P.B. Wildgoose: Cytokinin activity of commercial aqueous seaweed extract. Plant Sci. Lett., 1, 241-245(1973).

Chen, X., H. Yuan, R. Chen, L. Zhu, B. Du, Q. Weng and G. He: Isolation and characterization of triacontanol-regulated genes in rice (Oryza sativa L.): Possible role of triacontanol as a plant growth stimulator. Plant Cell Physiol., 43, 869-876 (2002).

Das, B., B.R. Jana, P. Dey and V. Nath: Assimilate partitioning behaviour in relation to fruit growth in 'Sahi' litchi. Int. J. Fruit Sci., 11, 88-98 (2011).

Deng, Z., X. Zhang, W. Tang, J.A. Oses-Prieto, N. Suzuki, J.M. Gendron, H. Chen, S. Guan, R.J. Chalkley, T.K. Peterman, A.L. Burlingame and Z.Y. Wang: A proteomics study of brassinosteroid response in Arabidopsis. Mol. Cell. Proteo., 6, 2058-2071 (2007).

Dodd, I.C.: Root-to-shoot signalling: Assessing the roles of "up" in the up and down world of long-distance signalling in planta. Plant Soil, 274, 251-270 (2005).

Estornell, L.H., J. Agusti, P. Merelo, M. Talon and F.R. Tadeo: Elucidating mechanisms underlying organ abscission. Plant Sci., 199-200, 4860 (2013). 
Frioni, T., P. Sabbatini, S. Tombesi, J. Norrie, S. Poni, M. Gatti and A. Palliotti: Effects of biostimulant derived from the brown seaweed Ascophyllum nodosum on ripening dynamics and fruit quality of grapevines. Sci. Hortic., 232, 97-106 (2018)

Ghosh, S.N.: Effect of plant growth regulators on fruit retention and physico-chemical properties of mango cv. Amrapali grown inlaterite soil at close spacing. J. Crop. Weed, 12, 83-85 (2016).

Halliday, K.J.: Plant hormones: The interplay of brassinosteroids and auxin. Curr. Biol., 14, R1008-R1010 (2004).

Khan, A.S., B. Ahmad, M.J. Jaskani, R. Ahmad and A.U. Malik: Foliar application of mixture of amino acids and seaweed (Ascophylum nodosum) extract improve growth and physico-chemical properties of grapes. Int. J. Agric. Biol., 14, 383-388 (2012).

Kumaravelu G., V.D. Livingstone and M.P. Ramanujam: Triacontanolinduced changes in the growth, photosynthetic pigments, cell metabolites, flowering and yield of green gram. Biol. Planta., 43, 287$290(2000)$

Manna, D., A. Sarkar and T.K. Maity: Impact of biozyme on growth, yield and quality of chilli (Capsicum annuum L.). J. Crop Weed, 8, 40-43 (2012)

Mohamed, A.Y. and O.A.M. El-Sehrawy: Effect of seaweed extract on fruiting of Hindy Bisinnara mango trees. J. American Sci., 9, 537544 (2013).

Momin, S.K., S.S. Gaikwad, R.J. Patel, J.J. Amarcholi and K.M. Sharma: Effect of foliar application of chemicals on fruiting parameters of mango (Mangifera indica L.) cv. Kesar. Res. J. Agric. Sci., 7, 143144 (2016).

Morales-Payan, J.P. and C.D. Candelas: Increasing organic avocado fruit yield using a Ascophyllum nodosum biostimulant and fertilization. Acta Hortic., 1042, 121-124 (2014).

Mostafa, L.Y. and H.R.M. Kotb: Effect of brassinosteroids and gibberellic acid on parthenocarpic fruit formation and fruit quality of Sugar Apple Annona squamosa L. Middle East J. Agric. Res., 07, 13411351 (2018).

Naeem, M., M. Masroor A. Khan and Moinuddin: Triacontanol: A potent plant growth regulator in agriculture. J. Plant Interact., 7, 129-142 (2012).

Norrie, J.: Ascopyllum nodosum extracts: Gifts from Poseidon to Theoi Georgikoi (The Greek Gods of Agriculture). Acta Hortic., 1148, 112 (2016).
Patil, A.S., S.N. Tidke, M.A. Tike, B.N. Shinde and M.A.K. Gore: Effect of chemicals and growth regulators on fruit set and fruit retention of Parbhani Bhushan mango. J. Soils Crops, 15, 64-66 (2005).

Pipattanawong, N., N. Fujishige, K. Yamane and R. Ogata: Effects of brassinosteroid on vegetative and reproductive growth in two dayneutral strawberries. J. Japan Soc. Hortic. Sci., 65, 651-654 (1996).

Prakash, S. and S. Ram: Effect of various concentrations of auxins and their time of application on fruit retention in mango (Mangifera indica L.) cv. Chausa. Prog. Horti., 18, 167-174 (1986).

Ram, S.: Naturally occurring hormones of mango and their role in mango growth and drop of the fruit. Acta Hortic., 321, 400-411 (1992).

Ramani, M.M., C.R. Patel, K.M. Sharma, J.J. Amarcholi and A.H. Patel: Effect of 28-homobrassinolide and shoot thinning on vegetative growth, flowering and yield of mango cv. Kesar. Adv. Life Sci., 5, 7097-7099 (2016).

Sawicki, M., E.A. Barka, C. Clement, N. Vaillant-Gaveau and C. Jacquard: Cross-talk between environmental stresses and plant metabolism during reproductive organ abscission. J. Exp. Bot., 66, 1707-1719(2015).

Sheoran, O.P., D.S. Tonk, L.S. Kaushik, R.C. Hasija and R.S. Pannu: Statistical Software Package for Agricultural Research Workers. In: Recent Advances in information theory, Statistics \& Computer Applications (Eds: D.S. Hooda and R.C. Hasija). Department of Mathematics Statistics, CCSHAU, Hisar, pp. 139-143 (1998).

Shukla, P.S., E.G. Mantin, M. Adil, S. Bajpai, A.T. Critchley and B. Prithiviraj: Ascophyllum nodosum-based biostimulants: Sustainable applications in agriculture for the stimulation of plant growth, stress tolerance, and disease management. Front. Plant Sci., 10,655(2019).

Singh, R.S. and S. Ram: Studies on the use of plant growth substances for fruit retention in mango cv. Dashehari. Indian J. Hort., 40, 188194 (1983).

Singh, Z., A.U. Mallik and T.L. Davenport: Fruit drop in mango. In: Horticultural Reviews (Ed.: J. Janick). John Wiley \& Sons, Inc., Hoboken, NJ, USA, pp.111-153 (2005).

Wally, O.S.D., A.T. Critchley, D. Hiltz, J.S. Craigie, X. Han, L.I. Zaharia, S.R. Abrams and B. Prithiviraj: Regulation of phytohormone biosynthesis and accumulation in Arabidopsis following treatment with commercial extract from the marine macroalga Ascophyllum nodosum. J. Plant Growth Regul., 32, 324-339 (2013). 